\title{
Coke, char and organic waste behaviour in the blast furnace with high injection rate ${ }^{(\cdot)}$
}

\author{
H.W. Gudenau*, D. Senk*, K. Fukada**, A. Babich*, C. Froehling*, L.L. García**, \\ A. Formoso ${ }^{* * * *}$, F.J. Alguacil ${ }^{* * * *}$ y A. Cores ${ }^{* * * *}$
}

Bbstract
of nut coke causes a change in coke quality requirements. In particular, not burned in the
raceway residues of injected substances (char and ash) can influence the coke behaviour.
Therefore combustion efficiency of various organic wastes with and without pulverized coal
injection (PCI) and coal char has been investigated under the raceway simulation
conditions. Mixing of various substances improves their combustion efficiency. Study on
coke gasification by carbon dioxide in the presence of char showed that with the increase
of char concentration, coke strength reduction becomes smaller. The reactivity of char
with $\mathrm{CO}_{2}$ is higher than that of coke. Therefore char is consumed preferentially. In
presence of injected char, total pore volume in coke and its wear resistance were increased.
Coke reactivity and microstructure in the presence of various kinds of ash has been studied.
Many ash spheres were observed on the surface of coke matrix and its size was dependent
on ash properties.

Keywords Blast furnace. Coke. Degradation. Tuyere injection. Auxiliary hydrocarbons.

\section{Comportamiento del coque, char y residuos orgánicos en el horno alto con altas tasas de inyección}

Resumen La operación del horno alto con una tasa baja de coque, una cantidad elevada de hidrocarburos auxiliares y el empleo de coque calibrado, origina un cambio en las necesidades de calidad del coque. En particular, pueden influir en el comportamiento del coque los residuos inquemados en el raceway (cavidad enfrente a las toberas del horno) de las sustancias que se inyectan (char y cenizas). El char es el residuo de carbón que se origina después que el carbón libera sus sustancias volátiles. Por tanto, se ha investigado la eficiencia de la combustión de varios residuos orgánicos con y sin inyección de carbón pulverizado (ICP) y char, bajo las condiciones de simulación del raceway. La mezcla de varias sustancias mejora la eficiencia a la combustión. El estudio de la gasificación del coque por el dióxido de carbono en la presencia de char, muestra que con el aumento de la concentración del char, la resistencia del coque después de la reducción se hace más pequeña. La reactividad del char con el $\mathrm{CO}_{2}$ es más elevada que conla del coque. Por tanto, el char se consume con preferencia. En presencia del char inyectado aumentan el volumen total de poros del coque y la resistencia al desgaste. Se ha estudiado la reactividad y microestructura del coque con la presencia de distintos tipos de cenizas. Se observaron muchas esferas de ceniza sobre la superficie matriz del coque y el tamaño de las esferas depende de la naturaleza de las cenizas.

Palabras clave Horno alto. Coque. Degradación. Inyección por toberas. Hidrocarburos auxiliares.

(•) Trabajo recibido el día 22 de julio de 2003 y aceptado en su forma final el día 17 de octubre de 2003.

$(*)$ Dept. of Ferrous Metallurgy, Aachen University, Intzestr. 1, D-52056 Aachen, Germany

(**) Ironmaking \& Environmental Process Research Dept. JFE Steel Corporation, Fukuyama, Hiroshima, Japan.

${ }^{(* * *}$ Centro de Investigaciones Metalúrgicas (CIME), Avda. 51, 23611, Ciudad de La Habana, Cuba.

(***) Centro Nacional de Investigaciones Metalúrgicas (CENIM/CSIC), Avda. Gregorio del Amo, 8, 28040 Madrid (España). 


\section{INTRODUCTION}

High productivity blast furnace operation while reducing costs is a target of integrated steelmakers. Coke constitutes a major portion of the production costs of hot metal. Except for economical aspects coke consumption is strongly related to the $\mathrm{CO}_{2}$ emission and therefore to environmental problems.

Many investigations in the Dept. of Ferrous Metallurgy at the Aachen University since 1982 have been focused on reducing carbon dioxide emission and its utilisation ranging from storage of $\mathrm{CO}_{2}$ in the deep sea for controlling underground coal gasification and optimization of petroleum conveying to the decrease of energy consumption in blast furnace and sinter processes. Currently studies on the use of natural gas and carbonaceous materials in direct reduction processes, drop in energy consumption in shaft furnace are being carried out with the target of lowering $\mathrm{CO}_{2}$ emission $^{[1]}$.

In 1991 in the National Center for Metallurgical Research (CENIM), at Madrid, Spain, a pilot scale combustion chamber was built, to simulate the conditions in the tuyere zone of blast furnace and to study the coal gasification ${ }^{[2-5]}$. In 1998 at Gijon a coke gasification chamber was built (Fig. 1), within the scope ACERALIACENIM collaboration, to study in pilot scale the raceway dimensions and the gas circulation when the pulverized coal injection (PCI) by tuyeres is carried out $\left.{ }^{[6 \text { and }} 7\right]$. The raceway is the influence zone of the reducing gases placed in front of each tuyere of the blast furnace. This cavity has a extent of 0.6 to $1.5 \mathrm{~m}$.

Decreasing the coke rate has been a priority since the beginning of the $18^{\text {th }}$ century when coke was introduced into the blast furnace instead of charcoal by A. Darby. Operating improvements have been remarkable over the years. In 2002 the coke rate made up $358 \mathrm{~kg} / \mathrm{tHM}$ in Western Europe (EU-15) ${ }^{[8]}$. The $\mathrm{CO}_{2}$ emission of German blast furnaces is in the range 1533 to $1651 \mathrm{~kg}$ $\mathrm{CO}_{2} / \mathrm{tHM}^{[9]}$.

The lowest coke rate will be achieved when the value of coke demand as heat supplier, reducing and carburising agent and supporting structure to ensure permeability will be minimum and maximum

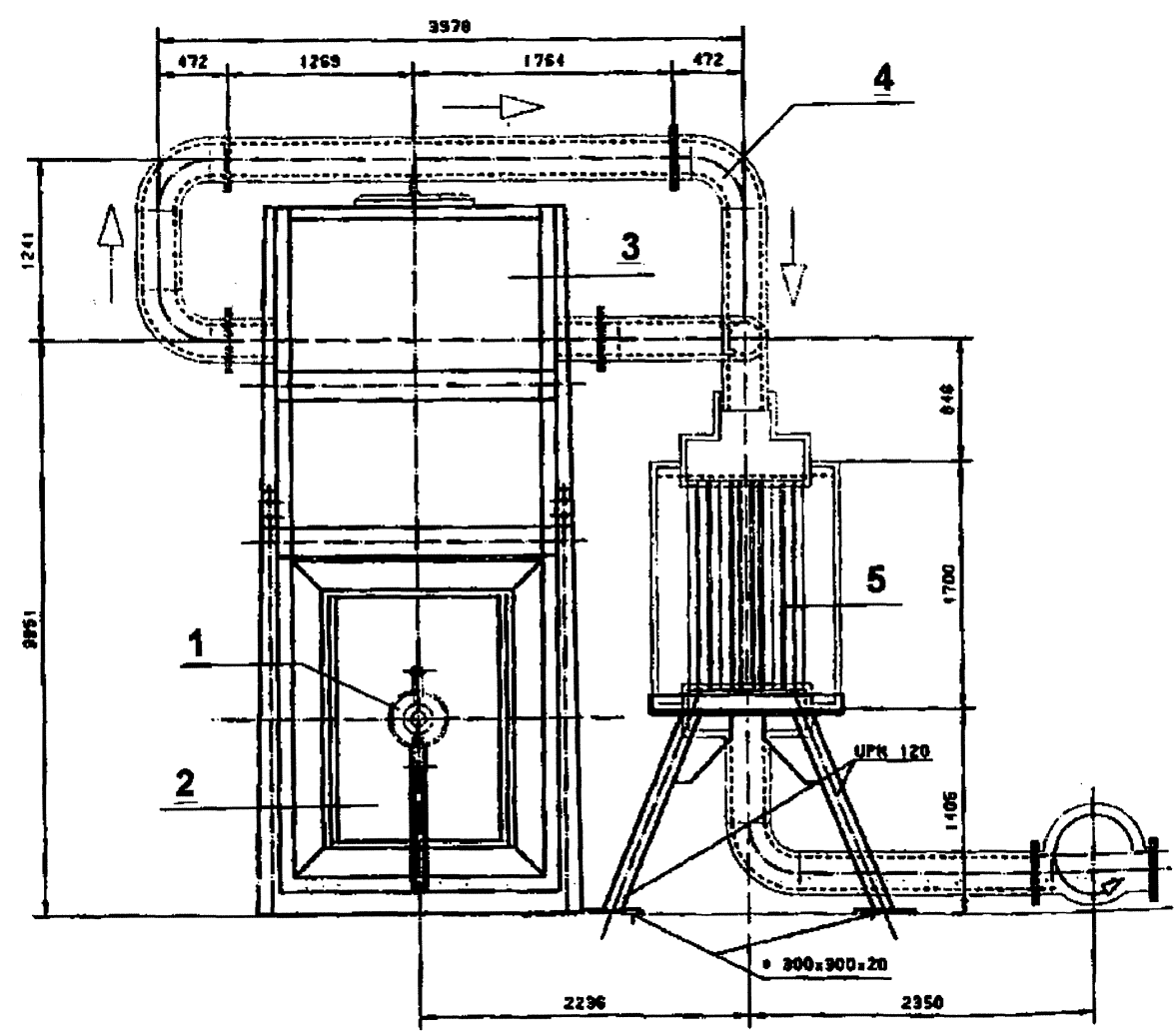

Figure 1. Coke gasification rig: 1 - Tuyere; 2 - Coke chamber; 3 -Weighting platform with a capacity of 30 ;; 4 - Outlet gas; 5 - Water cooler for outlet gases.

Figura 1. Instalación de gasificación del coque: 1 - Tobera; 2 - Cámara de coque; 3 - Plataforma de pesada con una capacidad de 30 t; 4 - Sistema de aspiración; 5- Refrigeración con agua de los gases de salida. 
possible rate of these demands (except for ensuring the gas permeability) will be covered by injected auxiliary substances. Therefore the methods for coke saving can be classified in two groups:

- Process improvements including coke quality.

- Substitution of coke with other reductants.

Injection of auxiliary reducing agents has been within the last two decades the main way for decrease in the coke rate. Therefore coke quality and injection technologies are closely related.

High quality coke is required to ensure sufficient gas permeability especially in the cohesive zone and drainage of liquid products in the hearth while high rate of PCI or other injected agents ${ }^{[10]}$. The diversity of injection conditions (injection of waste plastics, shredder residues in the mixture or separately of pulverized coal PC and other fossil auxiliary fuels) changes gas distribution in a blast furnace, unburned material type and alkali circulation behaviour. These changes influence the coke degradation behaviour strongly. An increased amount of coke fines has been observed at the lower part of a blast furnace with the increase of PCI rate ${ }^{[10-13]}$.

Principal factors causing the coke degradation in the blast furnace are mechanical stress such as shattering and abrasion, solution loss reaction, alkaline attack, high temperature attack and impact shock by high-speed hot blast (Fig. 2) ${ }^{[14]}$.

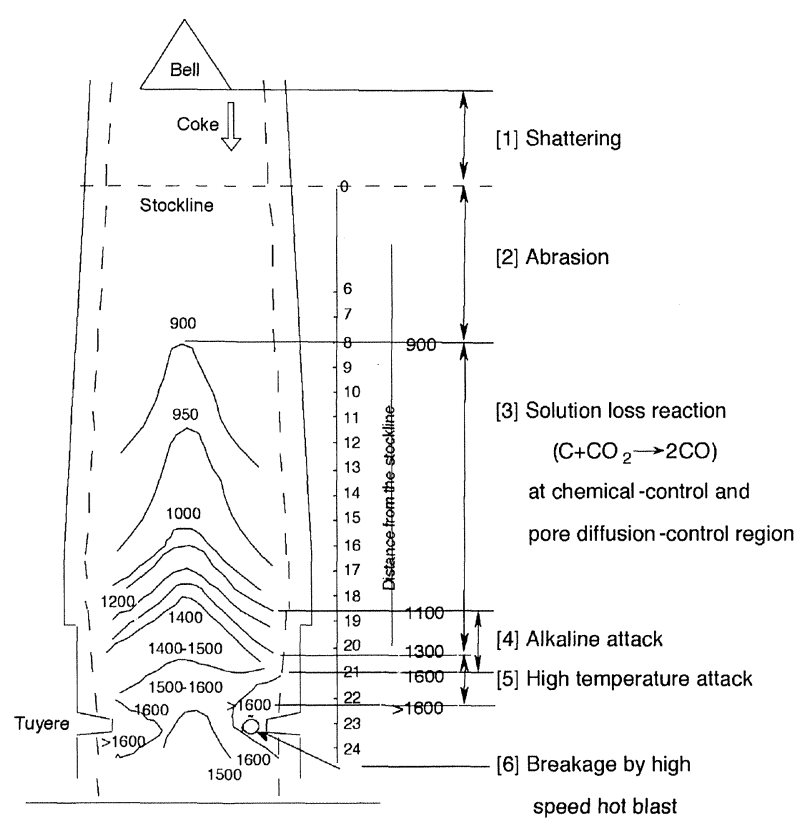

Figure 2. Coke degradation factors ${ }^{[15]}$.

Figura 2. Factores de degradación del coque ${ }^{[15]}$
Nowadays, coke cold strength and coke strength after reaction (CSR) are the standard characteristics of coke quality ${ }^{[15]}$. However, conventional parameters simulate only partial phenomena in the blast furnace ${ }^{[16]}$. Therefore there is a real need for suitable coke quality in the term of coke degradation behaviour under the modern blast furnace operation conditions with injection of PC, plastics or other substances.

High rate of PCI can also affect coke behaviour in the blast furnace due to the possible char generated by incomplete coal combustion in the raceway.

This applies not only for PCI but also for injected organic wastes. Recycling of plastic packing and shredder residue is emphasized nowadays because of economical and ecological reasons.

Incomplete conversion of injected fuels leads to char generation and may cause drop in the gas permeability, dirtying of the dead man and finally a decrease in the furnace productivity and increase in the coke rate. High coke quality is necessary to limit the contamination of the furnace especially in the area of the dead man (which can be characterised e.g. by a Deadman Cleanliness Index ${ }^{[17]}$ ) as well as to guarantee the necessary hydraulic and gas dynamic conditions in the hearth.

The paper describes combustion efficiency of organic wastes and gasification of unburned coal with different ash content by oxygen, coke deterioration by reaction with carbon dioxide in presence of char and ash and coke carburisation behaviour in liquid metal.

\section{GASIFICATION OF CHAR AND ORGANIC WASTES BY OXYGEN}

The complete combustion in the raceway of high PC rate and other solid carbon containing substances like organic wastes can be hardly achieved because of the very short residence time. A part of injected carbonaceous materials, which is not gasified by oxygen of the blast, can be utilised by reactions of secondary gasification ${ }^{[10]}$. Examples of these reactions are direct reduction of iron oxides (injected via the tuyeres or contained in the slag passing through the tuyere zones) and reaction of unburned coal particles with carbon dioxide (Boudouard reaction). Mechanisms of these reactions in solid or liquid phases were discussed early $^{[18-21]}$. 
Incomplete combustion of $\mathrm{PC}$ or organic wastes in the raceway may also result in accumulation of unburned particles in the cohesive zone, dead man and slag affecting the furnace permeability and hence its productivity as well as slag viscosity and therefore its desulphurisation ability and finally hot metal quality.

$\mathrm{PCI}$ and char generation also influence coke behaviour, first of all its degradation. On the one hand, PCI increases the coke residence time especially in the lower part and therefore intensifies disintegration of coke. Besides this, char reactivity towards $\mathrm{CO}_{2}$ is much higher than coke reactivity and therefore is consumed preferentially in the furnace. The faster reaction of char and hence disappearance results in slower movement of stock, permeability disturbances, change in heat level in the lower furnace part and shift of cohesive zone level.

On the other hand, more rapid gasification of unburned PC particles compared with lump coke may inhibit coke degradation in the raceway. It depends mainly on PC combustion efficiency ${ }^{[19]}$.

Therefore this part of the work was focused on the study of gasification behaviour in the oxygen atmosphere of coal char with high ash content, plastics and shreddered light fractions of car recycling with and without PC. Combustion efficiency of PC itself was studied in previous works, e.g. ${ }^{[18]}$.

Above mentioned materials with varying parameters and injection rate were tested under tuyere and raceway simulation conditions.

\subsection{Experimental set-up and tested materials}

Laboratory rig built up at the Dept. of Ferrous Metallurgy (Fig. 3) was used to investigate gasification of injected carbon containing materials under blast furnace conditions in the raceway ${ }^{[22}$ and 23$]$. The samples are blown in a preheated gas $\left(1000{ }^{\circ} \mathrm{C}\right)$ by a shock wave simulating the hot blast. It is mixed with the hot gas and blown through a $1700{ }^{\circ} \mathrm{C}$ zone simulating the raceway. Test duration is about $20 \mathrm{~ms}$ (corresponds to the residence time in the raceway). The combustion gas is analysed on-line $\left(\mathrm{O}_{2}, \mathrm{CO}_{2}\right.$, $\mathrm{CO}, \mathrm{CH}_{4}$ and $\mathrm{H}_{2}$ ) to calculate the combustion efficiency. The solid remainders are collected and analysed. The injection rig operates with pure oxygen and transferability of obtained results to the real process is provided by the choice and calculation of $\mathrm{O} / \mathrm{C}$ atomic ratio.

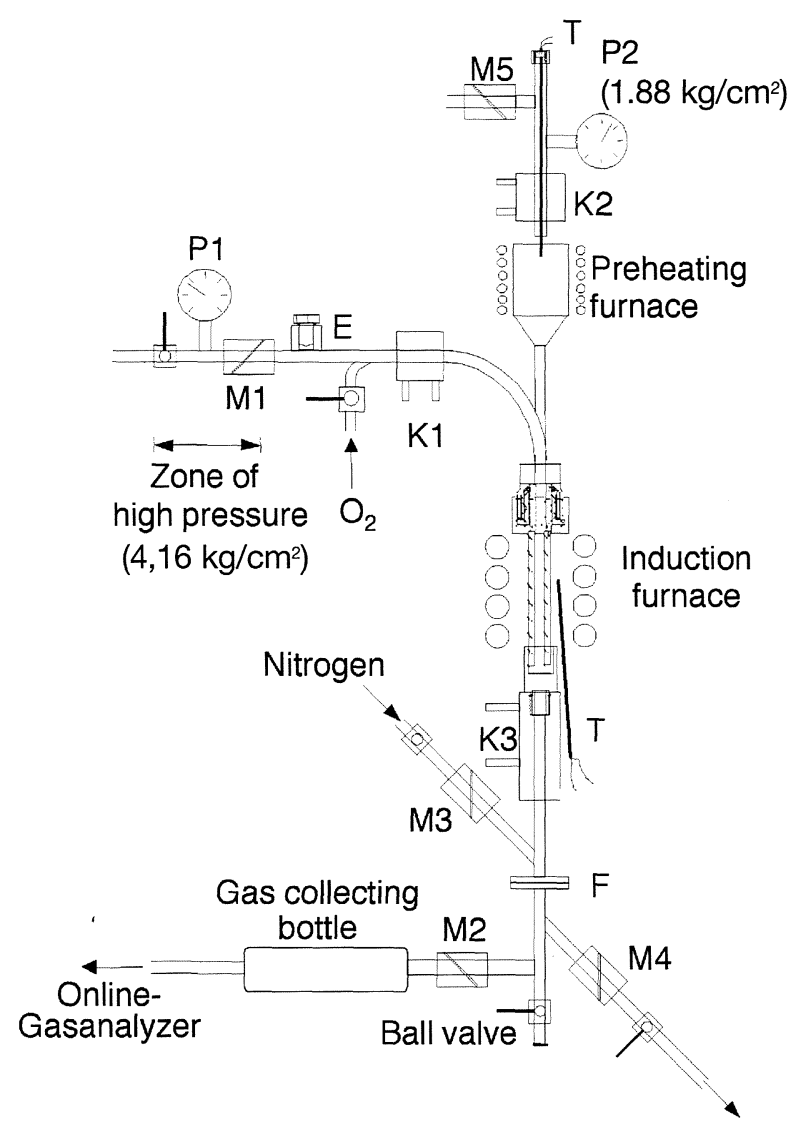

Figure 3. Schematic view of the laboratory injection rig: $\mathrm{E}$ - sample inlet, $\mathrm{F}$ - filter, $\mathrm{K}$ - cooling, $\mathrm{M}$ - magnetic valve, $P$ - pressure gauge, $T$ - thermocouples.

Figura 3. Esquema del equipo de inyección a escala de laboratorio: E - entrada de la muestra, $F$ - filtro, $K$ - enfriamiento, $M$ - válvula magnética, $P$ - medida de presión, $\mathrm{T}$ - termopar.

Following materials have been tested:

- Shredder light scrap fractions (SLF) from a car recycling process.

- Waste plastics (WP) from the German waste plastic recycling system "Duales System Deutschland".

- Coal char or unburned carbon (UBC).

These materials have also been investigated in mixture with PC from the German mine Niederberg. SLF and WP have been grinded up to the size of below $200 \mu \mathrm{m}, \mathrm{PC}$ and UBC mean size was under $100 \mu \mathrm{m}$. Compositions of tested materials are given in table I.

\subsection{Results and discussion}

The results of tests with these materials are shown in figure 4. It can be seen, that the pure UBC 
Table I. Analysis of injected materials

Tabla I. Análisis de materiales inyectados

\begin{tabular}{lcccccccc}
\hline Material & \multicolumn{2}{l}{$\begin{array}{l}\text { Proximate } \\
\text { analysis, wt. \% }\end{array}$} & & \multicolumn{4}{c}{$\begin{array}{c}\text { Ultimate analysis, } \\
\text { wt. \% }\end{array}$} \\
\cline { 2 - 3 } \cline { 6 - 8 } & Ash & VM & & C & H & N & S \\
\hline UBC & 32.5 & 2.0 & 61.6 & 0.7 & 0.8 & 0.4 \\
WP & 4.9 & 95.0 & 76.4 & 9.8 & 0.3 & 0.1 \\
SLF & 30.0 & 46.0 & 46.0 & 5.7 & 0.9 & 0.6 \\
PC & 9.03 & 10.8 & 85.40 & 3.65 & 1.52 & 0.87 \\
\hline
\end{tabular}

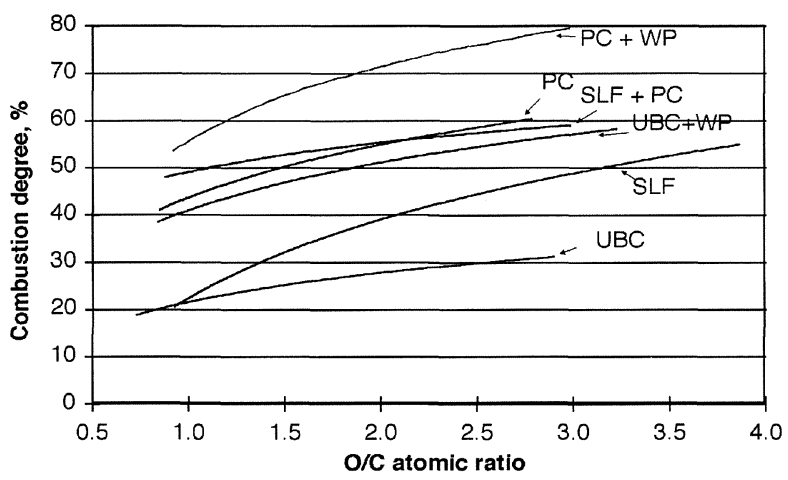

Figure 4. Combustion behaviour of various substances and their mixtures.

Figura 4. Comportamiento de la combustión de varias substancias y sus mezclas.

fraction is characterised by a very low combustion degree which is caused by the unreactive carbon, high ash content and obviously due to the decrease of particle surface area when reaching a certain burn-off level due to the coalescence of pores ${ }^{[24]}$. Adding plastics to the UBC strongly increased the combustion degree since the high volatile plastics improves the ignition behaviour of the unreactive carbon.

Not only combustion efficiency of char but also of raw $\mathrm{PC}$ can be improved by WP addition. In both cases (UBC+WP and PC+WP) mixtures with $30 \%$ of plastics have been used. Recent hot model experiments at NKK also showed that combustibility of PC-plastics mixture is higher than this value for each component ${ }^{[25]}$.

Efficiency of pure SLF injection into blast furnace is also hardly reachable due to the low content of combustible elements (carbon and hydrogen) and high ash content. It is possible to use this material as igniter for PC (especially for low volatile coals) because of its relatively high content of volatile matter so that the combustion degree increases by about $30 \%$ at $20 \%$ of SLF in the mixture.

It can be concluded that injection of mixtures of materials with different properties in a certain proportions may not only maintain the use of substances which are gasified badly in the pure state but also increase the combustion efficiency of PC.

\section{COKE DEGRADATION DUE TO REACTION WITH CO2 IN THE PRESENCE OF CHAR}

\subsection{Experiments}

A high temperature reactor has been used to investigate the coke gasification behaviour with $\mathrm{CO}_{2}$ gas in presence of char. Schematic illustration of this apparatus is shown in figure $5^{[26]}$. It consists of gas supply equipment, char feeder, reactor and mass spectrometer. The inside of the reactor can be heated up to $1500{ }^{\circ} \mathrm{C}$. A sample vessel with the internal diameter of $75 \mathrm{~mm}$ is set up in the centre of the reactor. Coke samples with an average diameter of 7,5 $\mathrm{mm}$ are charged into the vessel to a constant initial weight of $350 \mathrm{~g}$ in each experiment. Gas is fed at a constant flow rate of 35 $\mathrm{Nl} / \mathrm{min}$ to the bottom of the reactor. During the heating-up period only nitrogen is used. Reaction gas and char supply begins in parallel with gasification test and stops when the coke reaction rate achieves $20 \%$. Experiments have been conducted under different temperatures, gas compositions and char concentrations.

Coke strength after reaction was evaluated by tumbler test machine with $130 \mathrm{~mm}$ internal diameter and $210 \mathrm{~mm}$ length. Coke weight of samples over $2.8 \mathrm{~mm}$ was measured after revolution.

\subsection{Results and discussion}

Figure 6 shows coke strength after reaction with $\mathrm{CO}_{2}$ under different char concentrations measured by tumbler tester ${ }^{[27]}$. With the increase of char concentration, coke strength becomes higher.

To investigate the influence of char presence on coke reactivity mechanism, pore size distribution in coke sample after reaction was measured by mercury intrusion porosimetry. Figure 7 shows the relationship between pore diameter and cumulative pore volume. It can be seen that there is no difference among samples under $10 \mu \mathrm{m}$ in 


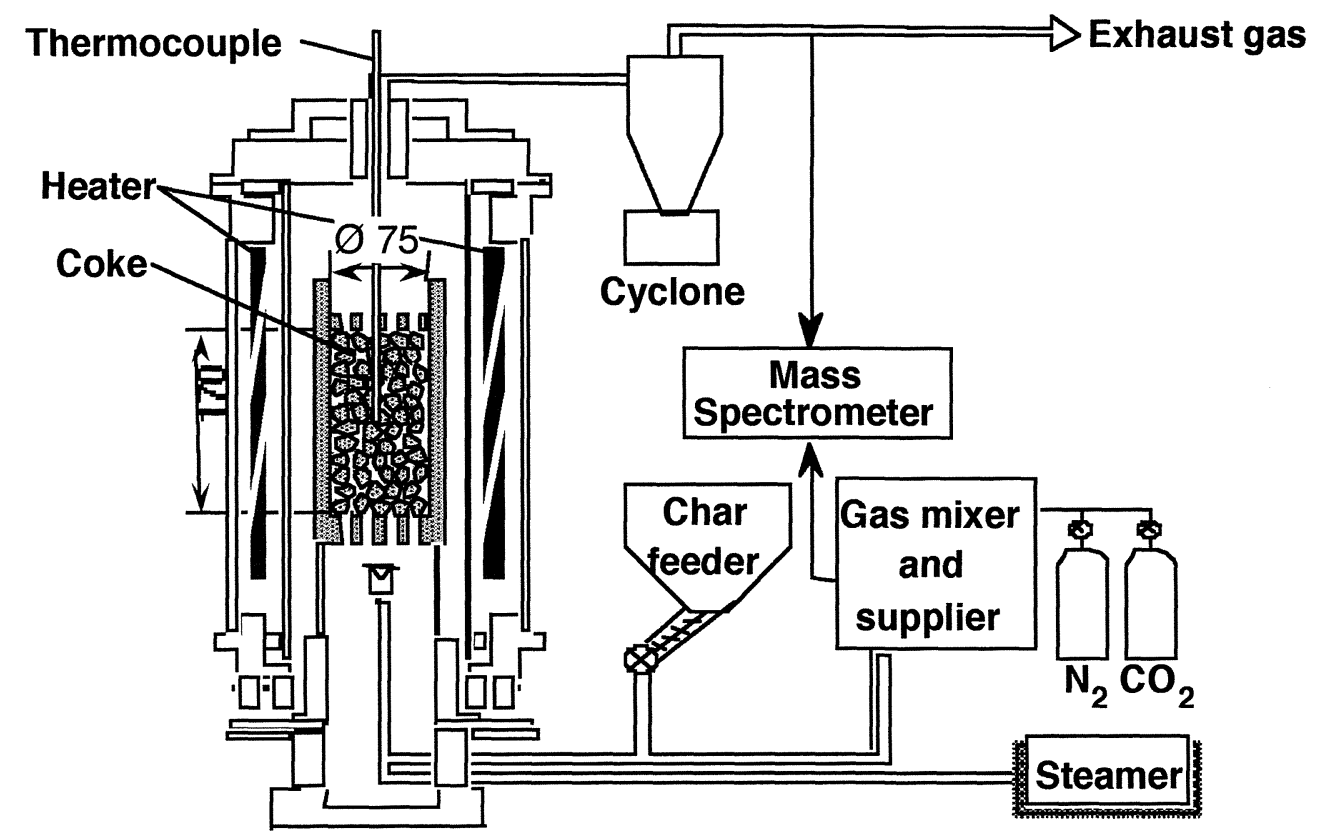

Figure 5. Schematic illustration of high temperature reactor ${ }_{t}^{[27]}$

Figura 5. Esquema del reactor de alta temperatura ${ }^{[27]}$

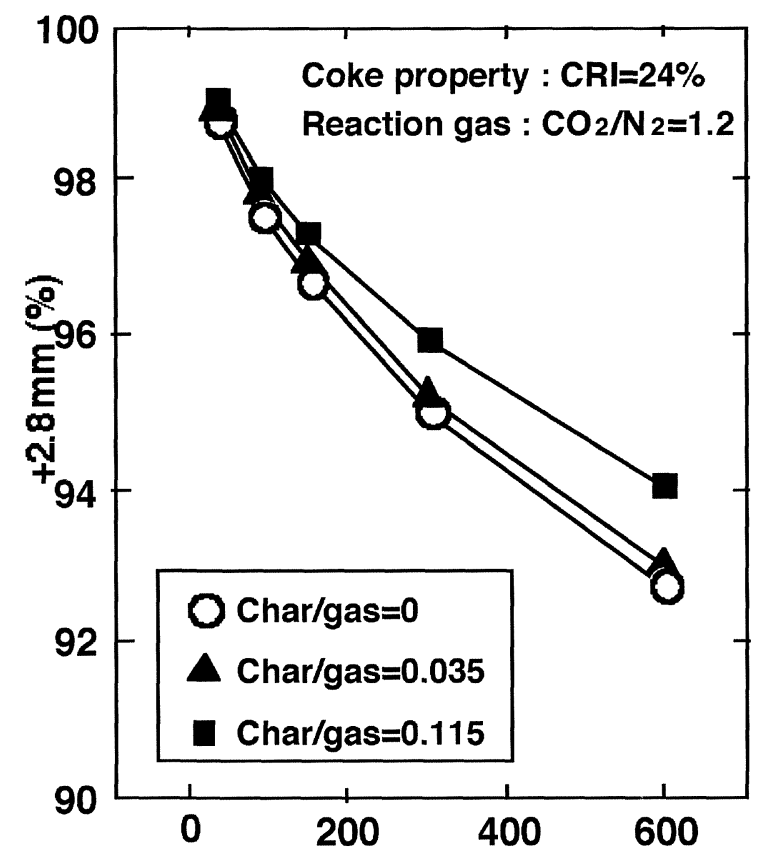

Cumulative number of tumbler revolutions

Figure 6. Coke surface breakage after gasification by $\mathrm{CO}_{2}$.

Figura 6. Degradación de la superficie del coque después de la gasificación por $\mathrm{CO}_{2}$.

pore size. However, a big difference is observed for pore size over $10 \mu \mathrm{m}$. Pore volume over $10 \mu \mathrm{m}$ increased with the rise of char concentration.

It is considered that the reactivity of char with $\mathrm{CO}_{2}$ is higher than that of coke and char is

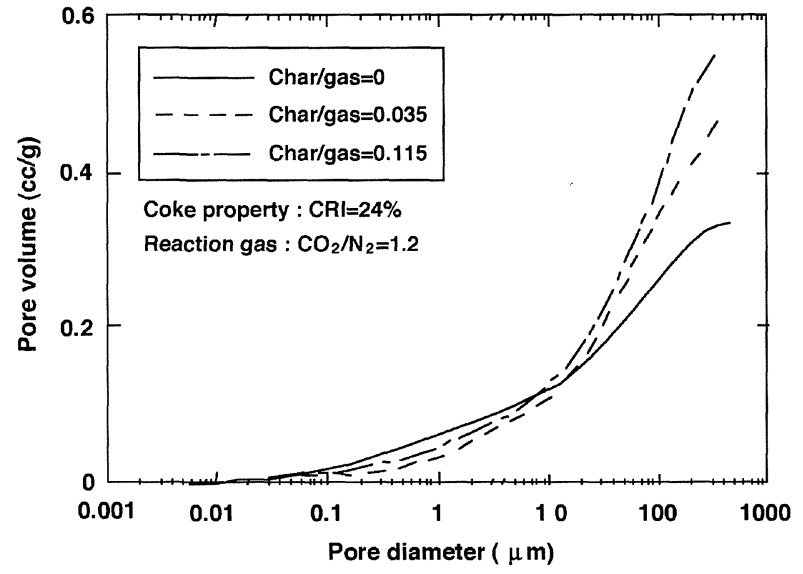

Figure 7. Change in pore size distributions with char concentration ${ }^{[28]}$

Figura 7. Cambio en la distribución del tamaño de poro con la concentración de inquemados ${ }^{[28]}$.

preferentially consumed so that $\mathrm{CO}_{2}$ concentration around a coke particle went down and reaction layer in a coke particle expanded around surface layer into inside. In the presence of char, the distribution of reaction ratio in coke particle changed and it affected coke degradation behaviour.

Char presence gave a positive effect on coke degradation behaviour in these experiments. However, coke strength is determined by factors of matrix strength and pore structure. An opposite result would have been obtained in the case of 
lower strength or high reactivity coke. Therefore it is necessary to carry out further investigations on coke degradation behaviour considering the effect of coke strength and reactivity.

\section{EFFECT OF ASH ON COKE REACTIVITY AND MICROSTRUCTURE}

Coke reaction test has been carried out with residue after combustion of coal and plastics. The coke microstructure change after the test has been estimated.

\subsection{Sample preparation and test performance}

Cokes with different coke reactivity index (CRI) and coke strength after reaction (CRS) values were used for coke reaction test. Tables II and III show coke properties and coke ash composition respectively. Ash composition of the two studied cokes is similar. To investigate the effect of ash derived from auxiliary fuel on coke behaviour in a blast furnace, coal ash was attached on the surface of coke. Its chemical composition is shown in table IV. Ashes $\mathrm{A}$ (with maximum $\mathrm{K}_{2} \mathrm{O}$ content), $\mathrm{B}$ (maximum $\mathrm{CaO}$ ) and $\mathrm{C}$ (maximum $\mathrm{TiO}_{2}$ ) were chosen to simulate the difference between injected coal and plastics from the German Waste Plastic Recycling System (Duales System Deutschland DSD).
Table II. Coke properties

Tabla II. Propiedades del coque

\begin{tabular}{|c|c|c|c|c|c|c|c|c|c|}
\hline \multirow[t]{2}{*}{ Coke } & \multirow{2}{*}{\multicolumn{2}{|c|}{$\begin{array}{l}\begin{array}{l}\text { Proximate } \\
\text { analysis, wt \% }\end{array} \\
\text { Ash V.M. FC }\end{array}$}} & \multicolumn{5}{|c|}{$\begin{array}{l}\text { Ultimate } \\
\text { analysis, wt \% }\end{array}$} & \multirow[b]{2}{*}{ CRI } & \multirow[b]{2}{*}{ CRS } \\
\hline & & & $C$ & $\mathrm{H}$ & $\mathbf{N}$ & $S$ & 0 & & \\
\hline A & 12.2 & 1.583 .6 & 85.8 & 0.21 & 1.14 & 0.43 & 0.22 & 29.5 & 58.7 \\
\hline B & 10.6 & 1.288 .2 & 86.9 & 0.20 & 1.11 & 0.56 & 0.63 & 24.7 & 65.2 \\
\hline
\end{tabular}

Coke reaction tests have been carried out by the combination set-up of Tamman furnace with scale (Fig. 8). Coke samples are of cylindrical shape with $20 \mathrm{~mm}$ diameter and $20 \mathrm{~mm}$ height. Reaction temperatures were 900,1100 and $1300{ }^{\circ} \mathrm{C}$. Reaction gas consisted of a mixture of $20 \% \mathrm{CO}_{2}$ and $80 \%$ Ar. The amount of attached ash was kept constant in all experiments $\left(0.08 \mathrm{~kg} / \mathrm{m}^{2}\right)$. Coke samples were reacted with reaction gas until the rate of the solution loss reaction became $20 \%$.

Coke microstructure before and after reaction was investigated by scanning electron microscope and optical microscope (SEM). Image processing software was used to evaluate pore and cell wall structure.

\subsection{Results}

- Reaction rate. Figure 9 shows Arrhenius plots for coke $A$ and coke $B$ respectively. In the

Table III. Coke ash composition

Tabla III. Composición de las cenizas del coque

\begin{tabular}{|c|c|c|c|c|c|c|c|c|c|c|c|c|c|}
\hline \multirow[t]{2}{*}{ Coke } & \multicolumn{13}{|c|}{ Ash composition, wt \% } \\
\hline & $\mathrm{SiO}_{2}$ & $\mathrm{Fe}_{2} \mathrm{O}_{3}$ & $\mathrm{Al}_{2} \mathrm{O}_{3}$ & $\mathrm{CaO}$ & $\mathrm{MgO}$ & $\mathrm{Na}_{2} \mathrm{O}$ & $\mathrm{K}_{2} \mathrm{O}$ & $\mathrm{SO}_{3}$ & $\mathrm{MnO}$ & $\mathrm{Ba}$ & $\mathrm{TiO}_{2}$ & $\mathrm{P}_{2} \mathrm{O}_{5}$ & $\mathrm{Cu}$ \\
\hline A & 53.66 & 6.25 & 28.52 & 2.76 & 1.22 & 0.48 & 0.94 & 1.66 & 0.04 & 0.21 & 1.39 & 0.75 & 0.02 \\
\hline B & 54.15 & 3.36 & 35.28 & 1.66 & 0.73 & 0.49 & 0.77 & 1.11 & 0.02 & 0.40 & 1.31 & 0.22 & 0.01 \\
\hline
\end{tabular}

Table IV. Chemical composition of coal ash

Tabla IV. Composición de las cenizas del carbón

\begin{tabular}{|c|c|c|c|c|c|c|c|c|c|c|c|c|c|}
\hline \multirow[t]{2}{*}{ Ash } & \multicolumn{13}{|c|}{ Ash composition, wt \% } \\
\hline & $\mathrm{SiO}_{2}$ & $\mathrm{Fe}_{2} \mathrm{O}_{3}$ & $\mathrm{Al}_{2} \mathrm{O}_{3}$ & $\mathrm{CaO}$ & $\mathrm{MgO}$ & $\mathrm{Na}_{2} \mathrm{O}$ & $\mathrm{K}_{2} \mathrm{O}$ & $\mathrm{SO}_{3}$ & $\mathrm{MnO}$ & $\mathrm{Ba}$ & $\mathrm{TiO}_{2}$ & $\mathrm{P}_{2} \mathrm{O}_{5}$ & $\mathrm{Cu}$ \\
\hline$A$ & 45.00 & 12.50 & 20.80 & 7.80 & 1.10 & 0.70 & 6.10 & 2.20 & 0.09 & 0.14 & 2.00 & 0.60 & 0.05 \\
\hline B & 13.80 & 15.60 & 3.90 & 47.40 & 8.40 & 0.37 & 0.27 & 8.70 & 0.32 & 0.29 & 0.37 & 0.12 & 0.01 \\
\hline C & 44.40 & 12.80 & 25.30 & 6.80 & 0.90 & 0.30 & 2.90 & 1.30 & 0.07 & 0.40 & 3.20 & 0.50 & 0.03 \\
\hline
\end{tabular}




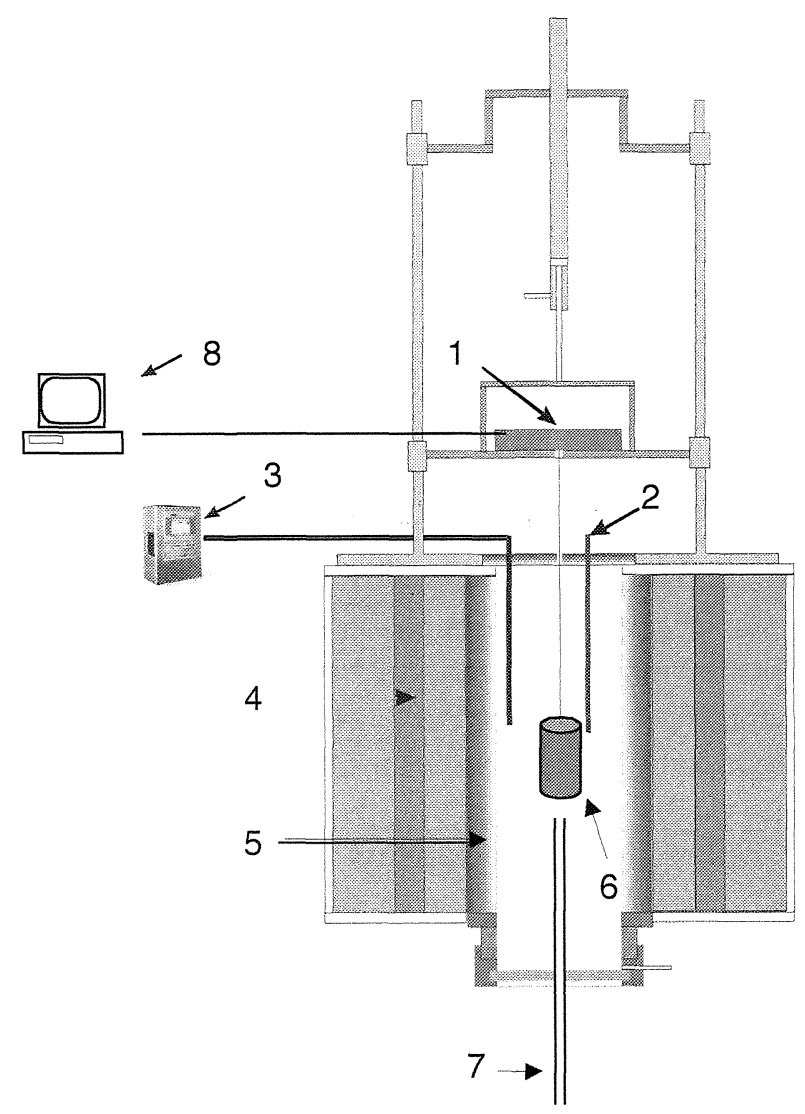

Figure 8. Schematic illustration of experimental set-up: 1 - electronic scale, 2 - thermocouple, 3 - gas analyser, 4 - ceramic tube, 5 - graphite tube, 6 - coke sample, 7 - gas supply, 8 - computer.

Figura 8. Esquema de la termobalanza experimental: 1 - escala electrónica, 2 - termopar, 3 - analizador de gas, 4 - tubo cerámico, 5 - tubo de grafito, 6 - muestra de coque, 7 - suministro de gas, 8 - computadora.

presence of additional ash coke reaction rate went up. This effect became small with the rise of reaction temperature or coke reactivity. These figures revealed that ash acts as a catalyst sufficiently though ash was concentrated only on the surface of coke. Catalytic effect of ash remained at $1300^{\circ} \mathrm{C}$. However the effect of ash on coke reactivity can be small in the lower part of blast furnace because catalytic agent (alkali) is concentrated there ${ }^{[28]}$.

- External structure change. Figure 10 shows SEM micrographs of coke surface after reaction at $1300{ }^{\circ} \mathrm{C}$ taken by scanning electron microscope. Many ash spheres are observed on the surface of coke. Ash derived from coke is generated on coke matrix as a film after the solution loss reaction so that their main origin was additional ash. A significant difference in the effect of the investigated ashes on the coke surface was recognised. Ashes $\mathrm{A}$ and $\mathrm{C}$ build a small number of big balls in coke pores whose mean diameter is $50-100 \mu \mathrm{m}$ and pore wall around ash balls seems weak. Ash B forms many globules of small size (approximately $10 \mu \mathrm{m}$ ) that cover coke surface uniformly. Ash spheres size depends on the viscosity, surface tension and adhesion of ash. Contact area between ash and coke matrix has also a big influence on the catalytic effect: the more this area the more strong the catalytic effect.

- Internal structure change. Coke samples that reacted at $1300{ }^{\circ} \mathrm{C}$ were evaluated with an optical microscope with magnification of 100 and the wall thickness between pores was measured with an image analyser. Figure 11 shows coke porosity with and without coal ash.

Position 0 on the $\mathrm{x}$-axis corresponds to the centre of the coke sample and position 1 corresponds to its border before reaction. High reactivity coke (coke $\mathrm{A}$ ) became smaller than low reactivity coke (coke $B$ ). The thickness of reaction layer in coke $A$ and $B$ was about $3 \mathrm{~mm}$ and $5 \mathrm{~mm}$ respectively (Fig.11 a). The difference of structure change was the development pattern of pore. Pore size in coke A became bigger with reaction, however in case of coke $B$, many small pores were generated relatively.

Coke size after reaction decreased in the following order: without attached ash, with ash A and then with ash B. This result corresponds fully to the result of the influence of ash on the reaction rate. Rate-determined step was changed from diffusion in particle to laminar film diffusion gradually by adhering high catalytic ash. Moreover reacted coke layer became thinner, from about 3 to $2 \mathrm{~mm}$ (Fig.11 b).

Coke strength (or wear resistance) is determined not only by pore structure but also by cell wall structure. To clarify the influence of ash on coke degradation behaviour, it is necessary to estimate also the change of pore cell structure.

Figure 12 shows the effect of coal ash on the coke structure. Y-axis means the survival rate of pore walls $(+50 \mu \mathrm{m})$. The order of reaction depth in this figure was the same as the result in figure 11. But there was one significant difference on the surface of coke. The survival rate of pore cell in coke with ash A was considerably lower compared with ash B. It means this coke has many pore walls under $+50 \mu \mathrm{m}$ on surface and coke in this area is destroyed or disappeared easily. 

H.W. Gudenau, D. SenK, K. Fukada, A: Babich, C. Froehling, L.L. García, A. Formoso, F.J. Alguacil y A. Cores
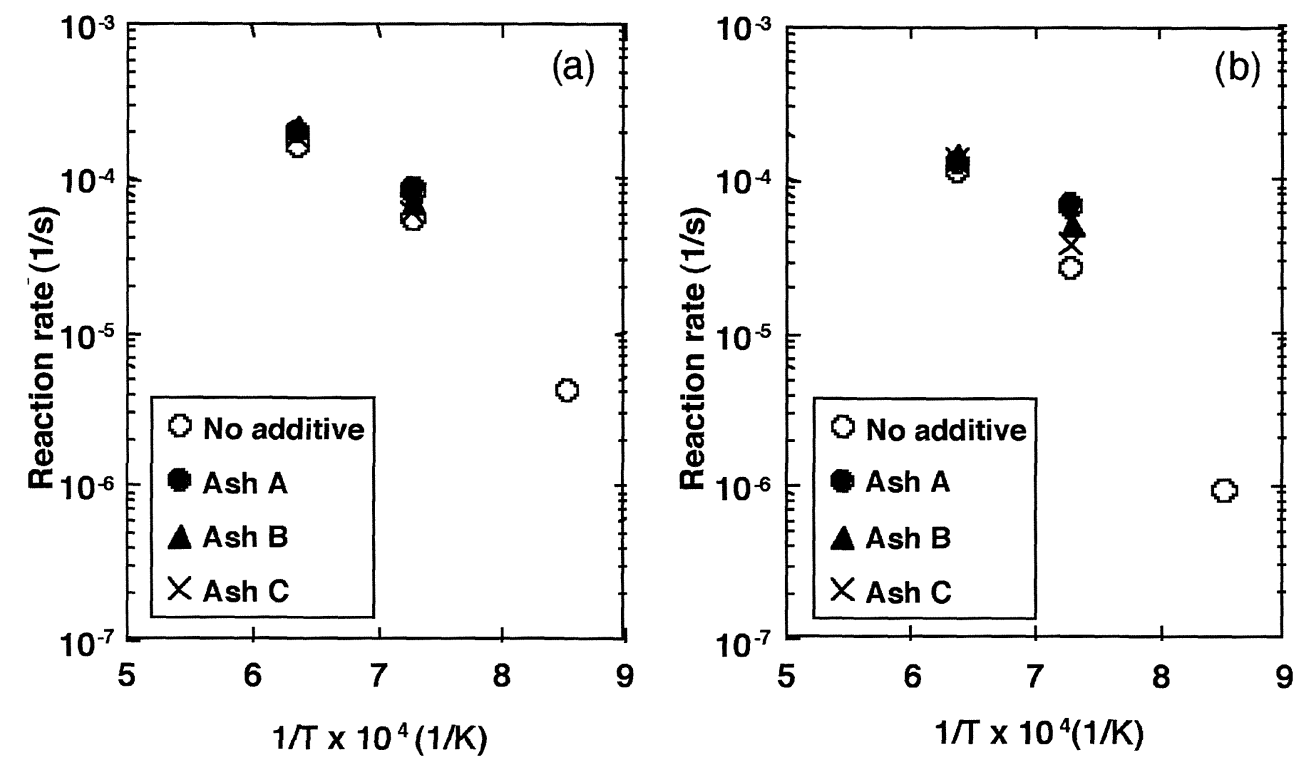

Figure 9. Coke reaction rate against temperature: a) coke $A$; b) coke $B$.

Figura 9. Tasa de reacción del coque en función de la temperatura: a) coque $A$; b) coque $B$.

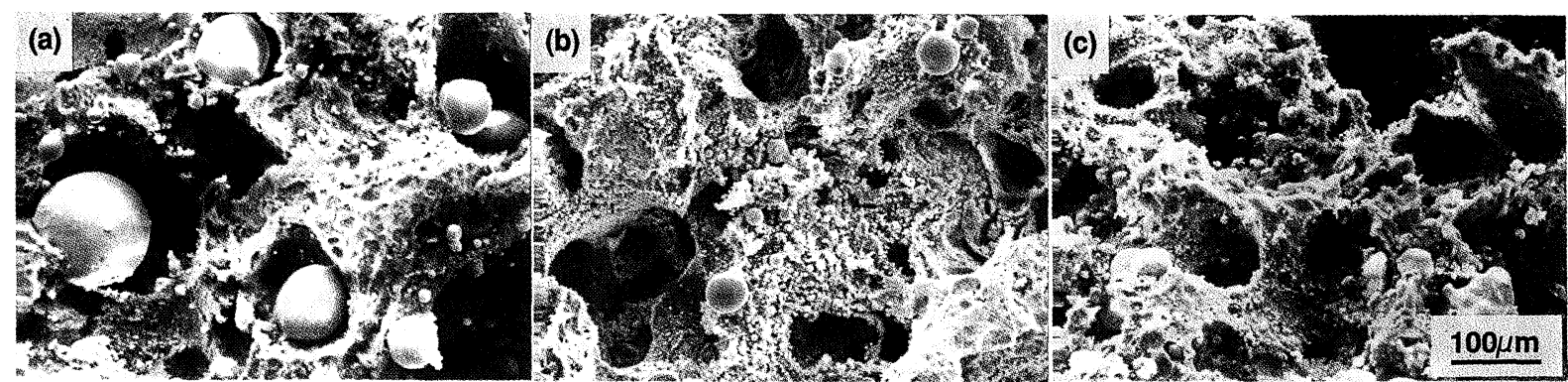

Figure 10. Scanning electron micrographs of coke surface affer reaction (X 200): a) coal ash A; b) ash $B ; c)$ ash $C$.

Figura 10. Micrografía por barrido electrónico de la superficie del coque después de la reacción (X 200): a) ceniza del carbón $A$; b) ceniza $B$; c) ceniza $C$.
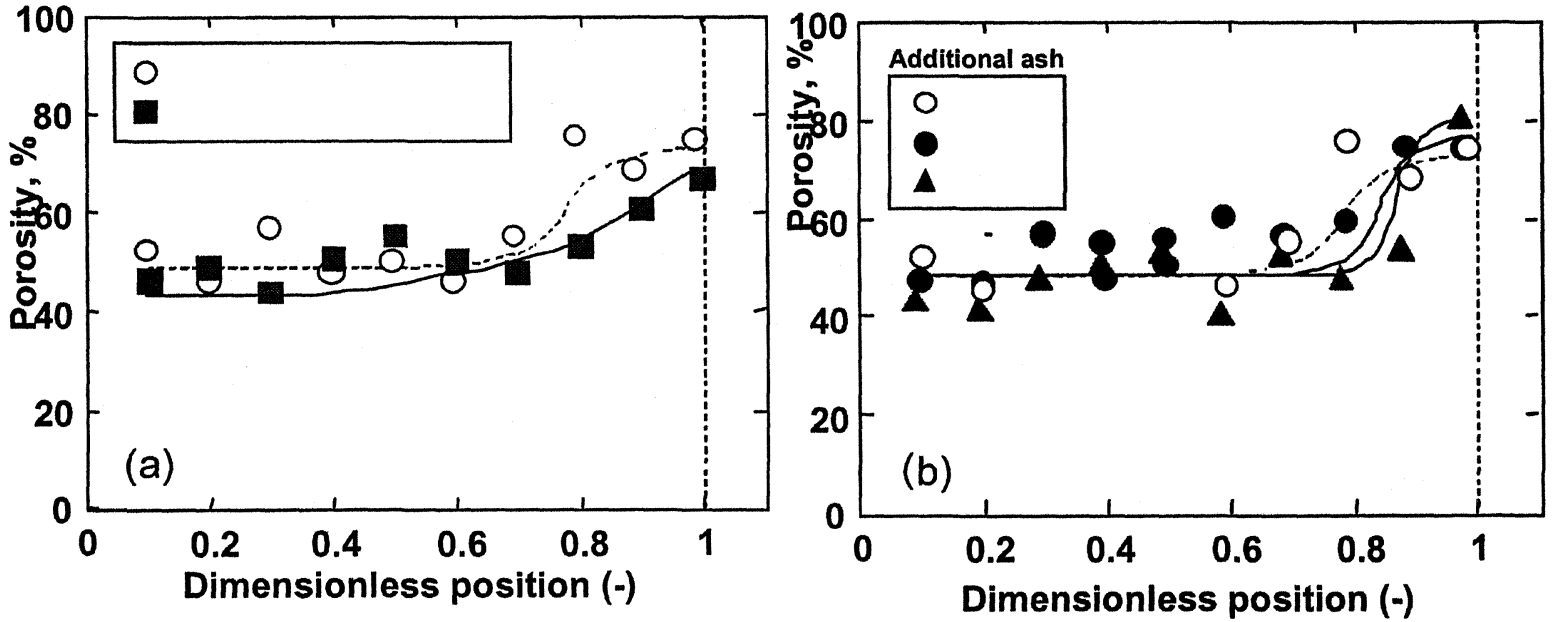

Figure 11. Effect of coke properties and coal ash on porosity distribution in coke.

Figura 11. Influencia de las propiedades del coque y la ceniza del carbón en la distribución de la porosidad en el coque. 


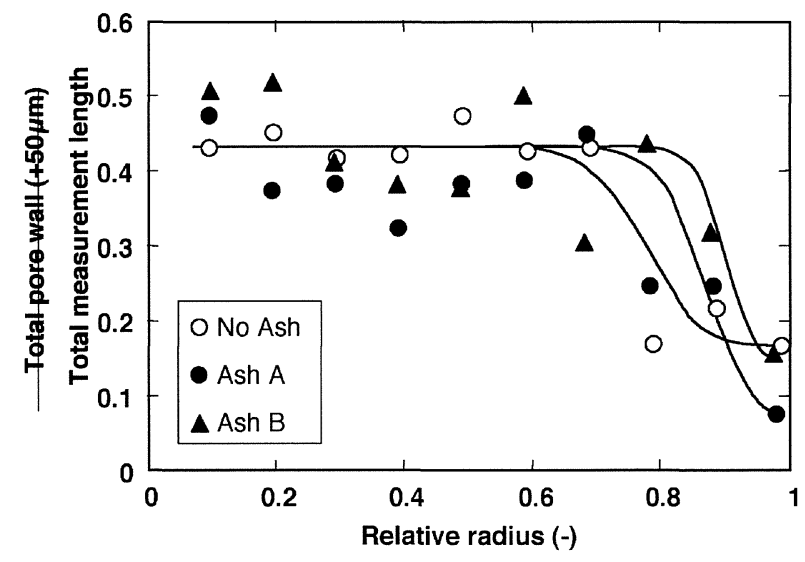

Figure 12. Effect of coal ash on the survival rate of pore wall.

Figura 12. Influencia de la ceniza del carbón en la tasa de supervivencia de la pared del poro.

\subsection{Discussion}

Additional alkali load due to injection of waste and recycling materials into the blast furnace is not implicitly bad from the viewpoint of coke consumption. Coke is reacted from its surface preferentially and it leads to high probability that big lumps of coke remain. But the following two problems still must be considered.

If big spheres of ash are generated in pores, pore walls around them are reacted preferentially compared to another parts of coke matrix. And then, the strength of this layer becomes too small and coke surface renewals fast because this reacted area becomes the starting point of peel (Figs.10, 12). As a result, coke size could decrease more considerably.

Moreover coke has many small fissures inside and reaction behaviour around them also should be clarified because cracks are source of volume breakage. In other words the development of crack could also be accelerated by an increase of coke reaction rate.

Ash, that forms many small globules on the coke surface, preserves it better from degradation compared to ash that forms a few large balls on the surface. But in the lower part of blast furnace, as a factor obstructive to permeability the decrease of coke size caused by volume breakage also must be considered.

\section{CONCLUSIONS}

- Study on char gasification by oxygen under the raceway simulation conditions showed that coal char has the lowest combustion behaviour among all tested materials due to the unreactive carbon and high ash content. High volatile matter substances accelerate ignition and combustion but it is usually not combined with high energy/carbon content. Injection of mixtures of materials with different properties in a certain proportions may provide the use of substances which are gasified badly in the pure state and also increase the combustion efficiency of PC.

- Coke strength after reaction with $\mathrm{CO}_{2}$ in the presence of char has been evaluated. Coke gasification mechanism is affected by char presence. A positive effect of char on coke degradation behaviour has been observed. The obtained result depends however on coke reactivity and strength which is determined by matrix strength and pore structure.

- Additional alkali load e.g., due to injection of waste and recycling materials into the blast furnace is not implicitly bad from the viewpoint of coke consumption. Coke is reacted from its surface preferentially and it leads to high probability to remain big lumps of coke. The ash of injected substances, which forms many small globules on the coke surface, preserves it from the degradation more strongly compare to that of large balls. Moreover in the lower part of blast furnace, as a factor obstructive to permeability, the decrease of coke size caused by volume breakage must be considered.

\section{Acknowledgements}

The authors are grateful to the "European Coal Steel Community" (ECSC) and JFE Steel Corporation for financial support of this work.

\section{REFERENCES}

[1] A. Babich, H.W. Gudenau and D. Senk, Proc. of $3^{\text {rd }}$ Int. Conf. on Sci. and Techn. of Ironmaking, Düsseldorf, 2003, pp. 89-94.

[2] A. Isidro, A. Formoso, J.J. Pis, S. Ferreira, E. Puente, L. García and A. Cores, Proc. Conf. VIII Int. Conf. on Coal Sci. and Tech., Vol. 1, Oviedo, Spain, Elsevier Science, 1995, pp. 551-554.

[3] A. Babich, S. Yaroshevskil, L. García, A. Formoso, A. Cores, A. Isidro and S. Ferreira, Rev. Metal. Madrid 32 (1996) 103-116.

[4] A. Formoso, A. Isidro and A. COREs, ECSC Agreement № 7210-AA938, 1998. 
[5] A. Formoso, A. Cores, A. Babich, H.W. Gudenau, L. García, S. Yaroshevskil and J.L. Menéndez, Rev. Metal. Madrid 37 (2001) 423-436.

[6] A. Formoso, A. Isidro and J. Vega, ECSC Agreement № 7210-AA938 (95-B.02b), 7210-AA939 (95.B.02d), (1999).

[7] A. Babich, H.W. Gudenau, D. Senk, A. Formoso, J.L. MenÉNDeZ and V. KoCHURA, Proc. Int. Blast Furnace Lower Zone Symposium, Wollongong, Australia, 25-27 November 2002, pp. 16.1-14.

[8] M. Peters and H.B. Lüngen, Proc. of $3^{\text {rd }}$ Int. Conf. on Sci. and Techn. of Ironmaking, Düsseldorf, 2003, pp. 33-39.

[9] K. Mülheims, H.B. Lüngen, U. SchierloH and P. STRICKER, Stahl Eisen 11 (2000) 1/22-1/24.

[10] H.W. Gudenau, K. Mavrommatis and A. Babich, Ironmaking, Lecture textbook, RWTH Aachen, 2002, p. 318, http://meveus.iehk.rwth-aachen.de/ textbook_html/ media/pages/index_ie.html

[11] M. ShimizU, R. Ito and K. Hoshino, CAMP-ISIJ 8 (1995) 6-9.

[12] K. IsHII, Advanced Pulverized Coal Injection Technology and Blast Furnace Operation, Elsevier Science Ltd, Oxford, (2000) p. 307.

[13] P. Negro, J.M. Steiler, E. Beppler, U. Jahnsen, C.R. Bennington and R.R. Willmers, Proc. of $3^{\text {rd }}$ Int. Cokemaking Congress, Gent, 1996, pp. 20-27.

[14] K. Matsubara, T. Miyazu and R. Takahashi, Proc. of Symposium on Gondwana Coals, Lisbon, 1983, pp. 161-173.

[15] R. Álvarez, J.L. García-Cimadevilla, M.A. Díez, J. Bermúdez, V. Alonso and E. Puente, Rev. Metal. Madrid 38 (2002) 380-387.
[16] M.A. Díez, R. Álvarez, N. Rodoslavov, C.S. Canga and J. Xiberra, Rev. Metal. Madrid 38 (2002) 410-418.

[17] R.J. Nightingale, F.W.B.U. Tanzil, A.J.G. Beck, J.D. DUNNING and S.K. VARDY, Proc. of 2nd Int. Congr. on Sci. and Technol. of Ironmaking and $57^{\text {th }}$ Ironmaking Conf. Proc., Toronto, 1998, pp. 567-579.

[18] A. Babich, S. Yaroshevskil, A. Formoso, A. Isidro, S. Ferreira, A. Cores and L. García, ISIJ Int. 36 (1996) 1250-1258.

[19] Y. IWANAGA, Ironmaking Steelmaking 19 (1992) 36-44.

[20] H.W. Gudenau, A. Babich, H. Denecke, S. YAROSHEVSKII and V. KochuRA, Stahl Eisen 12 (1999) 81-87.

[21] A. Babich, S. Yaroshevskil and V. TereshChenko, Intensifying pulverized coal use in blast furnace operation, Technic, Kiev, 1993, p. 200.

[22] S. Wippermann, PhD Thesis RWTH, Aachen, 1996.

[23] H.W. Gudenau, K. Stoesser, H. Denecke and V. SCHEMMANN, ISIJ Int. 40 (2000) 218-223.

[24] L. Lu, V. Sahajwalla and D. Harris, Metall. Trans. 32B (2001) 811-820

[25] K. Goto, R. Murai, A. Murao, M. Sato, M. Asanuma and T. ARIYAma, Proc. of Int. Blast Furnace Lower Zone Symp., Wollongong, Australia, 2002, Paper 1.

[26] K. Fukada, S. Itagaki, I. Shimoyama and H. Kadoya, CAMP-ISI.J 9 (1996) 140.

[27] K. Fukada, S. Itagaki, I. Shimoyama and H. Kadoya, CAMP-ISIJ. 9 (1996) 654

[28] W. Altpeter, E. Beppler, B. Gerstenberg and M. KANNAPPEL, Stahl Eisen 108 (1988) 781-790. 